\title{
Early Detection of Skin Cancer Using SAKURI in Satelit General Hospital of Aceh Besar
}

\author{
Wahyu Lestari' ${ }^{1}$, Sitti Hajar ${ }^{2}$, Fitria Salim ${ }^{3}$, Mulia Saputra ${ }^{4}$, Ade Irma Suryani ${ }^{5}$ \\ \{wahyu_lestari2000@yahoo.com ${ }^{1}$ \} \\ 1.2.3Faculty of Medicine, Syiah Kuala University, Banda Aceh \\ ${ }^{4.5}$ Faculty of Economics and Business, Syiah Kuala University, Banda Aceh
}

\begin{abstract}
The purpose of this service is to introduce the community to the importance of maintaining skin health through self-examination (SAKURI). The method of implementing community service activities is done using an approach method that involves all group members actively which the resulted the service will be more useful. This service activity aims to develop a technique for conducting early detection of skin cancer using SAKURI in order to take precautions as early as possible on the possibility of skin cancer and early detection of skin cancer which the treatment of the disease can be done as soon as possible and easily to avoid the complications. This program focuses on how self-examination (SAKURI) techniques for early detection of skin cancer are conducted and the action which plays a role in preventing skin cancer that can be done by patients. The results of the service found that almost $90 \%$ of the people did not know about the self-examination methods and knowledge of skin cancer is still rarely introduced. Most patients grow small flesh on their skin that spreads throughout the body and they allowed the situation. Therefore, we conducted intensive counseling and treatment to increase the awareness of the people in Indrapuri and the knowledge of medical personnel in the Satelite General Hospital. Then, it has resulted in increasing the understanding of the importance of SAKURI examining skin cancer and protecting the skin to avoid skin cancer. This community service is expected give the contribution to patients, medical personnel and paramedics to increase their knowledge and awareness to immediately be able to do a skin examination if signs of suspicious malignancy on the skin are found. It is expected that the results of this study can be a guideline for medical, paramedic and skin patients as a science which could be implemented in the future.
\end{abstract}

Keywords: Early Detection, Cancer, Sakuri, Aceh Besar

\section{Introduction}

Skin health is very important because along with changes in lifestyle to an unhealthy direction, increasing ultraviolet radiation, the effects of certain toxins, and also genetic factors, resulting in skin constituent cells experiencing uncontrolled growth which is commonly referred to as cells cancer. Skin tumors are growths or excessive lumps of skin tissue that affect part or all part of the skin layer. Skin tumors are divided into benign skin tumors, precancerous tumors, and malignant skin tumors, malignant skin cancer or cancer. In general, this disease can be detected early because it can be seen and touched from the beginning so that the supervision and discovery of skin tumors can be done carefully. Today's skin cancer tends to increase in number, especially in the Americas, Australia, and the UK. The World Health Organization estimates that in 2008 around the world there are around 2 million new cases each 
year for non-melanoma skin cancer, while melanoma skin cancers are around 132,000 new cases each year. ${ }^{5}$ Satellite General Hospital of Aceh Besar District is a type C RSU, located at, Jl. Banda AcehMedan KM.20 Sinyeu Indrapuri. In this community service, there were two partners, namely Satelite Hospital, Aceh Besar and community groups suffering from tumor/skin cancer.

The number of patient with skin cancer has increased in recent years. Indonesia is a tropical country with ultraviolet rays from the sun is very strong and most Indonesian people do activities such as farmers/seafarers who are directly exposed to the sun without using sun protection such as sunscreen, hats and the use of appropriate clothing so that it is very influential on the process of skin cancer. Skin cancer in Indonesia gets less attention because it rarely causes significant deaths and disorders so it tends to be less noticed.

From the results of observations at the Satelite Hospital, Aceh Besar, the first partners in this service can be explained as follows:

- The biggest obstacle is the lack of knowledge of patients, medical personnel and paramedics in Satelite Hospital, Aceh Besar regarding skin cancer and SAKURI for early detection of skin cancer.

- Limited facilities caused in limited action for tumor/skin cancer patients.

- Data on patients with skin cancer is still limited.

While the problems faced by the second partner, namely the community group suffering from tumors/skin cancer is a lack of health knowledge about skin cancer and SAKURI for early detection of skin cancer which affected the patients on late for treatment, severe conditions with complications, treatment is no longer possible at Satellites Hospital and it must be referred to type B or type A hospitals which required high expense.

\section{Methodology}

\subsection{Implementation Management}

The process of community services is conducted by identifying various problems as mentioned previously, then the stages or methods of implementation that need to be done as a solution to problem-solving are as follows.

\subsection{Preparation of the Program}

The most common cause of skin cancer is sun exposure, so an assessment of the knowledge of the side effects of sun exposure that can cause skin cancer is needed and knowledge of how to use SAKURI is still lacking.

\subsection{Preparation on Going Program}

Counseling of patients who are treated in poly skin and genitalia regarding clinical signs and symptoms of tumor/skin cancer. Expected medical personnel, paramedics and patients can perform SAKURI for early detection of skin cancer.

\subsection{Expected Result of the Program}

The society able to implement SAKURI regularly and observing the dermatologist if they find skin abnormalities that lead to skin cancer so that treatment can be done as early as possible and prevent complications that occur. 


\section{Community Service Result}

This community service was held in the Satelite Hospital Indrapuri, Aceh Besar. The sample of this study are all patients suffering from tumor and skin cancer. From the findings obtained in this service, all patients in the private hospital were not aware that they had experienced a benign skin tumor. These skin tumors occur due to exposure to direct sunlight without using a sun protector. The average occupation of the community in Indrapuri is as a farmer. In their work, they are always directly faced with sunlight and do not use skin protectors such as sunscreens, umbrellas, or hats. If it has happened continuously it will cause a benign skin tumor. The symptoms are small brownish lumps that appear on the skin and it can become larger and if it is not handled quickly it will turn into skin cancer. In the first stage, we reviewed the location in the Indrapuri hospital and looked at the condition of the patients especially those who had skin tumors.

From the observations, it was found that almost all patients who came for treatment were not aware of the origin of how these skin tumors could attack them. This is because the understanding and knowledge that they find are not enough to detect early causes of skin tumors. Untreated skin tumors will become skin cancer. Therefore proper understanding must be done immediately. Therefore, we provide counseling to patients and medical personnel at this Satelite Hospital. The Fig below is an extension activity that we do for patients with tumors and skin cancer in Indrapuri.

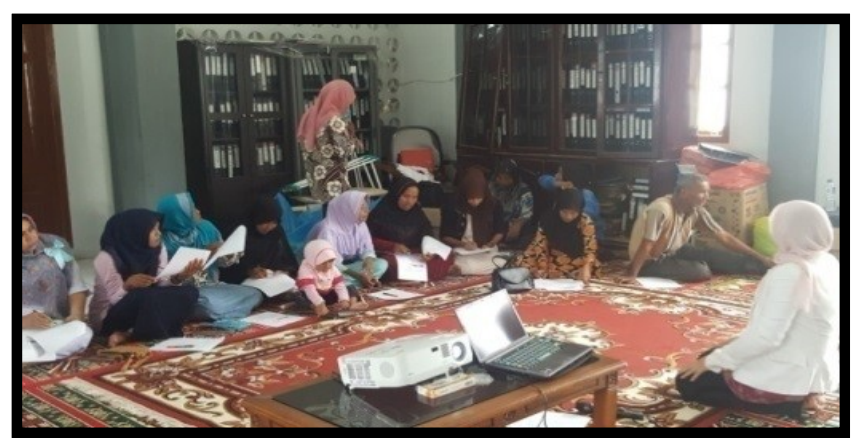

Fig 1. Health Conselling on Skin Cancer

In the Fig, the instructor is giving material and an understanding of the importance for early detection of skin cancer. If it left unchecked, it will be difficult for further treatment. With early detection of tumors and skin cancer can immediately take treatment quickly if there are symptoms of skin tumors.

After conducting counseling to patients and medical professionals, then conduct a thorough examination of patients with tumors and skin cancer. The following Fig exhibits the examination of the patient. 


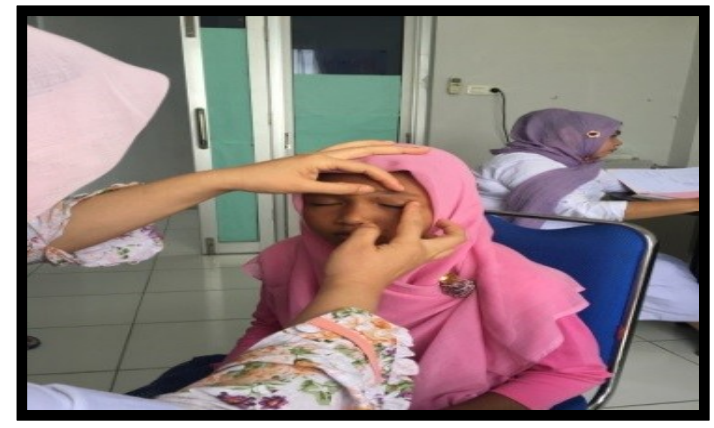

Fig 2. Skin Cancer Examination

The continuous examination found several types of tumors or skin cancer that are often experienced by patients in the area of Aceh Besar. The causes include because they often sunbathe in the heat because of farming and they do not maintain the cleanliness of their faces. Symptoms that often arise in the examination are as follows:

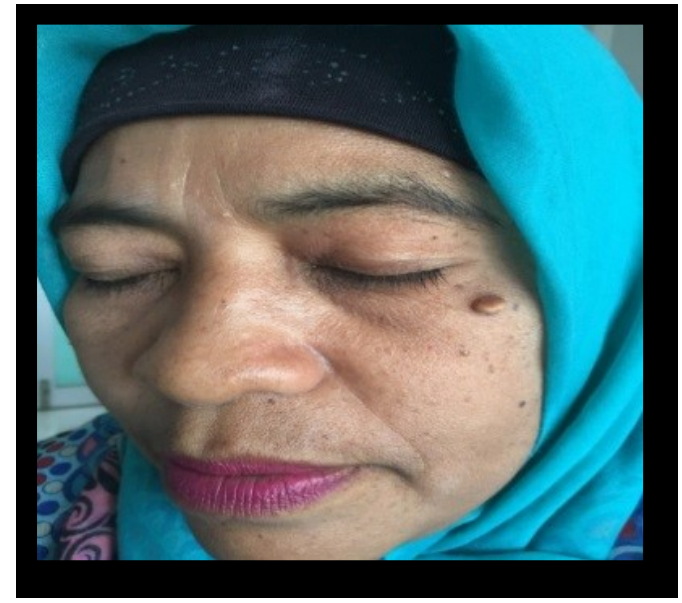

Fig 3. Skin Cancer Symptoms

Therefore, self-handling is done by providing explanations and knowledge to the community through continuous counseling to make them immediately know the symptoms of skin tumors and it can be addressed immediately. The best way to prevent early skin tumors is to regularly use sunscreens and consume antioxidant vitamins and avoid direct sun exposure. 
The three types of skin cancer can be seen from the following Figs:

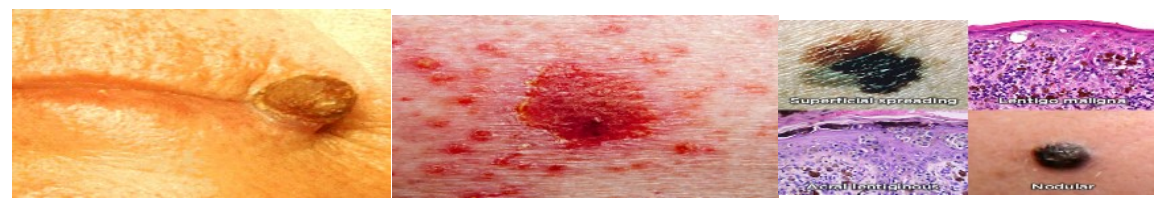

Fig 4. Skin cancer sufferers of Actinic Keratosis, Basal Cell Carcinoma, and Melanoma

Treatment of cancer patients and skin tumors continues to be conducted in this service. The implementation was held to patients who felt symptoms of cancer or tumors in the Satellite Hospital Aceh Besar. The purpose of treatment and action is for all patients who have been exposed to skin cancer to get initial therapy which the treatment and healing can be done immediately. The following Fig of the patient who performed the examination and treatment at the Satelite Hospital, Aceh Besar.

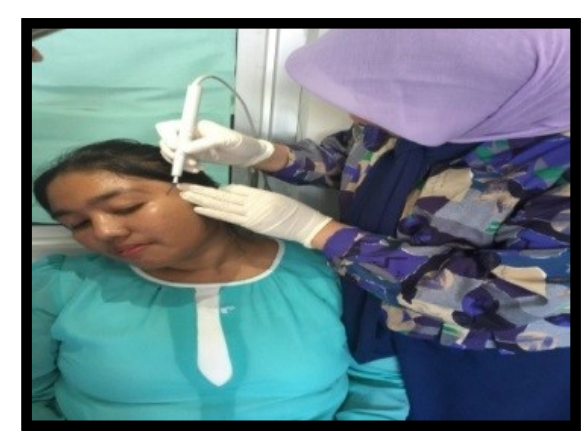

Fig 5. Counseling of Skin Cancer in Satelit Hospital Indrapuri

We are from the dedication team also provided skin vitamins and medicines to treat cancer and skin tumors. The drug and vitamin are in the form of ointment rubbed on the skin. It uses depends on the type of cancer. In addition, vitamins are also given to the skin in order to avoid skin cancer. The goal is that skin cancer can be avoided as early as possible so that our skin is always healthy and maintained. The following picture is the delivery of skin cancer prevention medicines and vitamins to patients and community members and both partners at Satellite Hospital in Indrapuri.

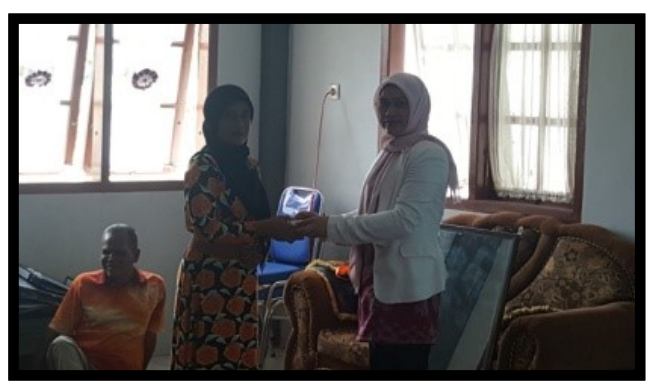

Fig 6. Providing vitamin and drug to prevent skin cancer 
In this community service activity, several improvements in public awareness of the importance of examining skin cancer in a sacred manner have been felt. This can be seen from the increasing number of people who want to see themselves to find out more about skin cancer. Before the service, there were crowded patients who complained about skin footage. For example, the patient complains about a lump on the skin. Through this service, the enthusiasm of the community to find out the skin examination was very crowded. Then, after they attend skin cancer health counseling and use the recommended drugs and vitamins, patients who have had skin cancer have been rapidly decreased.

Moreover, the best result which has been achieved by this community service program is proved by the decreasing number of skin cancer patients who previously had around 4 to 5 people a day who examined cancer problems in the skin, after the patient's service that examined skin cancer was reduced by more than $50 \%$. This is because the community has practiced skin screening in a sacred manner and it is relatively fast to take precautions. Finally, the treatment has been conducted in the event of early symptoms, it can be done quickly and precisely.

\section{Conclusion}

From the following community service activities, it can be concluded that the science and technology activities for the community have been running well supported by the village apparatus, the community and the leadership and staff of Satelite hospitals in Indrapuri.

Skin tumors are growths or excessive lumps of skin tissue that affect part or full part of the skin layer. Skin tumors are divided into benign skin tumors, precancerous tumors, and malignant skin tumors. The sun exposure continuously tends to be one of the causes of skin cancer. It changes such as shape, color, size, irregular edges, easy to bleed on the discharge/lumps/spots on the skin should be suspected of malignancy. Perform early detection on SAKURI regularly every once a month by checking the appearance or abnormal growth of the skin should be routinely performed. Then, consult quickly to health services if there are suspicious signs on the skin for immediate treatment.

Pemeriksaan yang dilakukan pada pasien di rumah sakit umum Satelit Indrapuri menemukan banyak gejala kanker kulit. Dengan pengabdian ini dapat membantu pasien dan masyarakat setempat termasuk semua kalangan yang berada di Rumah sakit umum satelit untuk dapat segera berkonsultasi ke dokter apabila ditemukan gejala kanker dari pemeriksaan sakuri. Hal ini agar penanganan segera dapat diatasi.

The examinations conducted on patients in Satelite Hospital Indrapuri finds many symptoms of skin cancer. With this service, it can help patients and the local community, including all people who are in the Satelite Hospital, enable to immediately consult a doctor if symptoms of cancer are found from the SAKURI examination. This action will help patients to get the handling immediately. 


\section{Reference}

[1] Granholm JM. Olszewski GJ, (2009) Facts about Skin Cancer. Michigan Department of Community Health.

[2] Grujil FRD. (2006) UV radiation, DNA damage, mutations and skin cancer. Dalam: Ghetti F, Checcucci G, Bornman JF, editor. Environmental UV radiation: Impact on ecosystems and human health and predictive models. Vol.57. Italia: Springer: Hal. 249-58.

[3] Hamzah M. (2001) Early detection of skin malignant tumors. In: Cipto H, Pratomo US, Handayani I, Sukarata K, editor. Detection and management of early skin malignant tumors. Jakarta: Balai Penerbit FKUI: 14-21.

[4] Hamzah MS, Effendi A. (2008), Skin tumors on RSUD Dr. Abdoel Moeloek Lampung. In: Buku Abstrak Kongres Nasional XII PERDOSKI Palembang:h. 151.

[5] Narayanan DL, Saladi RN,(2010) Fox JL. Ultraviolet radiation and skin cancer. International Journal of Dermatology ; 49: 978-86.

[6] Nouri K, Patel SS, Singh A.(2008) Etiology of skin cancer. In: Nouri K, Skin cancer. China: The McGraw-Hill Companies:39-45.

[7] Rahimah, Hari Sukanto 2009. Skin tumors Ultraviolet effects on the possibility of malignancy, part of the skin and genital diseases, FK Unair, Surabaya. Recommendation Statement, Annals of Internal Medicine, Volume 150, No.3.

[8] Rumah Sakit Dharmais Pusat Kanker Nasional. (2015) Self skin examination. Diakses melalui: www.dharmais.co.id/index.php/kanker-kulit.html

[9] Sibarani MNO, Dalimunthe DA, Putra IB. (2008), Skin tumors in the skin and genital clinic RSUP H. Adam Malik Medan. In: Buku Abstrak Kongres Nasional XII PERDOSKI Palembang : h. 77-8.

[10] Wu S, Han J, Laden F, Qureshi AA. (2014) Long-term ultraviolet flux, other potential risk factors, and skin cancer risk: A cohort study. Cancer Epidemiol Biomarkers Prev; 23(6): 1-10.

[11] World Health. (2006) Organization International Agency for Research on Cancer. Exposure to artificial UV radiation and skin cancer. Vol.1. IARC. 2006. 